\title{
RAHASIA DAGANG YANG DITERAPKAN PADA PERUSAHAAN PT BASUKI PRATAMA ENGINEERING
}

\author{
Tio Fernandes \\ 155100075, 785567885 \\ Fakultas Komputer \\ tiofernandes.student@umitra.ac.id
}

\begin{abstract}
Rahasia dagang adalah informasi yang tidak diketahui oleh umum di bidang teknologi dan/ atau bisnis dimana mempunyai nilai ekonomis karena berguna dalam kegiatan usaha, dan dijaga kerahasiaannya oleh pemilik rahasia dagang. Seperti yang disebutkan dalam Pasal 1 Undang-Undang Rahasia Dagang (UndangUndang Nomor 30 Tahun 2000)yang berbunyi, Rahasia Dagang adalah informasi yang tidak diketahui oleh umum di bidang teknologi dan/atau bisnis, mempunyai nilai ekonomi karena berguna dalam kegiatan usaha, dan dijaga kerahasiaannya oleh pemilik Rahasia Dagang.

Pemilik rahasia dagang dapat memberikan lisensi bagi pihak lain. Yang dimaksud dengan lisensi adalah izin yang diberikan kepada pihak lain melalui suatu perjanjian berdasarkan pada pemberian hak (bukan pengalihan hak) untuk menikmati manfaat ekonomi dari suatu rahasia dagang yang diberikan perlindungan pada jangka waktu tertentu dan syarat tertentu. Tidak dianggap sebagai pelanggaran rahasia dagang apabila:

- Mengungkap untuk kepentingan hankam, kesehatan, atau keselamatan masyarakat,

- Rekayasa ulang atas produk yang dihasilkan oleh penggunaan rahasia dagan milik orang lain yang dilakukan semata-mata untuk kepentingan pengembangan lebih lanjut produk yang bersangkutan.
\end{abstract}

Kata Kunci : Rahasia Dagang 


\section{A. INTRODUCTION}

Rahasia dagang adalah informasi yang tidak diketahui oleh umum di bidang teknologi dan/ atau bisnis dimana mempunyai nilai ekonomis karena berguna dalam kegiatan usaha, dan dijaga kerahasiaannya oleh pemilik rahasia dagang.

Seperti yang disebutkan dalam Pasal 1 Undang-Undang Rahasia Dagang (UndangUndang Nomor 30 Tahun 2000)yang berbunyi, Rahasia Dagang adalah informasi yang tidak diketahui oleh umum di bidang teknologi dan/atau bisnis, mempunyai nilai ekonomi karena berguna dalam kegiatan usaha, dan dijaga kerahasiaannya oleh pemilik Rahasia Dagang. Lingkup perlindungan rahasia dagang meliputi metode produksi, metode pengolahan, metode penjualan, atau informasi lain di bidang teknologi dan/atau bisnis yang memiliki nilai ekonomi dan tidak diketahui oleh masyarakat umum. Rahasia dagang mendapat perlindungan apabila informasi itu:

- Bersifat rahasia hanya diketahui oleh pihak tertentu bukan secara umum oleh masyarakat,

- Memiliki nilai ekonomi apabila dapat digunakan untuk menjalankan kegiatan atau usaha yg bersifat komersial atau dapat meningkatkan keuntungan

ekonomi,

- Dijaga kerahasiaannya apabila pemilik atau para pihak yang menguasainya telah melakukan langkah-langkah yang layak dan patut. Pemilik rahasia dagang dapat memberikan lisensi bagi pihak lain. Yang dimaksud dengan lisensi adalah izin yang diberikan kepada pihak lain melalui suatu perjanjian berdasarkan pada pemberian hak (bukan pengalihan hak) untuk menikmati manfaat ekonomi dari suatu rahasia dagang yang diberikan perlindungan pada jangka waktu tertentu dan syarat tertentu.

Tidak dianggap sebagai pelanggaran rahasia dagang apabila:

- $\quad$ Mengungkap untuk kepentingan hankam, kesehatan, atau keselamatan masyarakat,

- Rekayasa ulang atas produk yang dihasilkan oleh penggunaan rahasia dagan milik orang lain yang dilakukan semata-mata untuk kepentingan pengembangan lebih lanjut produk yang bersangkutan.

\section{B.Perkembangan Pengaturan Rahasia Dagang}

Pengaturan tentang rahasia dagang di Indonesia masih baru. Dasar dari pengaturan ini adalah diratifikasinya Agreement Establishing the World Trade Organization (persetujuan Pembentukan 
Organisasi Perdagang Dunia atau WTO) yang mencakup juga Agreement on Trade Related Aspects of Intellectual Property Rights (Persetujuan TRIPs) dengan UndangUndang No. 7 Tahun 1994 sehingga perlu diatur tentang rahasia dagang. Di Indonesia rahasia dagang diatur pertama kali melalui Undang-Undang No. 30 Tahun 2000 Tentang Rahasia Dagang. Pada awalnya perlindungan hukum menyangkut segala bentuk praktek-praktek persaingan tidak sehat telah diatur oleh rambu-rambu dan normanorma pada Pasal 1365 KUHPerdata dan Pasal 382 bis KUHP.

Namun kemudian menjadi masalah setelah tentang hal itu dikemas sebagai produk kekayaan intelektual. Ini berarti konsep unfair competition sebagai hukum yang bersifat umum lebih dipersempit atau difokuskan kepada hukum yang melindungi adanya praktek curang bermotif komersial. Kebuthan itu diformulasikan dalam Undang-Undang No. 30 Tahun 2000 Tentang Rahasia Dagang. Secara umum dapat dikatakan bahwa undangundang rahasia dagang ini juga melengkapi Undang-Undang No. 5 Tahun 1999 tentang Larangan Praktek Monopoli dan Persaingan Usaha Tidak Sehat.

\section{C.Lingkup Rahasia Dagang}

a. Subyek Rahasia dagang adalah pemilik rahasia dagang. Pemilik rahasia dagang memiliki hak untuk : 1) Menggunakan sendiri Rahasia Dagang yang dimilikinya;

2) Memberi lisensi kepada pihak lain atau melarang pihak lain untuk menggunakan Rahasia Dagang atau mengungkapkan Rahasia Dagang itu kepada pihak ketiga untuk kepentingan yang bersifat komersial.

b. Obyek ruang lingkup rahasia dagang menurut undang-undang No. 30 Tahun 2000 Pasal 2 meliputi metode produksi, metode pengolahan, metode penjualan atau informasi lain di bidang tekhnologi dan/atau bisnis yang memiliki nilai ekonomi dan tidak diketahui oleh masyarakat umum. Misalnya Coca-cola menggunakan rahasia dagang yaitu informasi teknik senyawa untuk melindungi formulanya, bukan paten. Hal ini untuk menghindari adanya batas waktu. Kalau formula dilindungi hak paten maka, akan berakhir paling lama 20 tahun. Pada saat ini usia Coca Cola sudah lebih dari 100 tahun, hak ini karena formulanya dilindungi dengan rahasia dagang. Metode produksi misalnya teknologi pemrosesan anggur, formula ramuan rokok. Di bidang lain, misalnya informasi non teknik. 
Data mengenai pelanggan, data analisis, administasi keuangan, dll.

c. Lama Perlindungan Beberapa alasan/keuntungan penerapan Rahasia Dagang dibandingkan Paten adalah karya intelektual tidak memenuhi persyaratan paten, masa perlindungan yang tidak terbatas, proses perlindungan tidak serumit dan semahal paten, lingkup dan perlindungan geografis lebih luas.Namun, tanpa batas waktu ini mempunyai syarat yaitu sebagaimana tercantum dalam Pasal 3 yaitu bahwa rahasia dagang dilindungi bila informasi tersebut masih bersifat rahasia, mempunyai nilai ekonomi, dan dijaga kerahasiaannya melalui upaya semestinya. Ketiga syarat yang harus dipenuhi itu dapat diuraikan sebagai berikut. a) Bersifat rahasia apabila informasi itu hanya diketahui oleh orang-orang terbatas. b) Informasi mempunyai nilai ekonomi apabila sifat kerahasiaan informasi tersebut dapat digunakan untuk menjalankan kegiatan usaha atau bisnis yang komersial atau mendatangkan keuntungan bagi pemiliknya.

c) dijaga kerahasiaannya apabila pemilik atau para pihak yang menguasainya telah melakukan langkah-langkah yang layak.

D.Pelanggaran dan Sanksi Barangsiapa dengan sengaja dan tanpa hak menggunakan dan mengungkapkan Rahasia Dagang, mengingkari kesepakatan atau mengingkari kewajiban tertulis atau tidak tertulis untuk menjaga Rahasia Dagang yang bersangkutan, atau pihak lain yang memperoleh/menguasai

Rahasia Dagang tersebut dengan cara yang bertentangan dengan peraturan perundangundangan yang berlaku, dipidana dengan pidana penjara paling lama 2 (dua) tahun dan/atau denda paling banyak Rp 300.000.000,00 (tiga ratus juta rupiah).

\section{E.Prosedur Perlindungan} Untuk mendapat perlindungan Rahasia Dagang tidak perlu diajukan pendaftaran (berlangsung secara otomatis), karena undang-undang secara langsung melindungi Rahasia Dagang tersebut apabila informasi tersebut bersifat rahasia, bernilai ekonomis dan dijaga kerahasiaannya, kecuali untuk lisensi Rahasia Dagang yang diberikan. Lisensi Rahasia Dagang harus dicatatkan ke Ditjen. HKI DepkumHAM.

\section{F.Pengalihan Hak dan Lisensi}

Hak atas Rahasia Dagang seperti hak atas kekayaan intelektual yang lain, merupakan benda bergerak tidak berwujud oleh karenanya dapat beralih atau dialihkan 
dengan

a. Pewarisan

b. Hibah

c. Wasiat

d. Perjanjian tertulis atau

e. Sebab-sebab lain yang dibenarkan oleh peraturan perundang-undangan

Pengalihan Hak Rahasia Dagang wajib didaftarkan pada Direktorat Jenderal Hak Kekayaan Intelektual. Lisensi adalah izin yang diberikan oleh pemegang Hak Rahasia Dagang kepada pihak lain melalui suatu perjanjian berdasarkan pada pembelian hak (izin) untuk menikmati manfaat ekonomi dari suatu rahasia dagang yang diberi perlindungan dalam jangka waktu tertentu dan syarat tertentu. Perjanjian pemberian lisensi/izin pada pihak lain untuk mempergunakan Rahasia Dagang atau mengungkapkan Rahasia Dagang itu untuk kepentingan yang bersifat komersial harus dibuat secara tertulis dan didaftarkan/dicatatkan pada Direktorat Jenderal HKI. Perjanjian lisensi dilarang memuat ketentuan yang dapat merugikan perekonomian di Indonesia atau yang mengakibatkan persaingan usaha tidak sehat sebagaimana diatur dalam peraturan perundang-undangan yang berlaku.

\section{G.Pendaftaran Permohonan Rahasia Dagang}

Hak kepemilikan rahasia dagang tidak perlu melalui prosedur pendaftaran. Kecuali pengalihan haknya.

\section{H.Litigasi dan Penyelesaian Sengketa Rahasia Dagang}

Pemilik Hak Rahasia Dagang atau penerima lisensi dapat menggugat siapa saja yang dengan sengaja dan tanpa hak melakukan perbuatan sebagaimana diatur pada Pasal 4 yaitu menggunakan rahasia dagang dan atau memberi lisensi kepada orang lain, atau mengungkapkan rahasia dagang kepada pihak ketiga untuk kepentingan komersial dengan gugatan ganti rugi dan atau minta penghentian tindakan yang dilakukan sesuai Pasal 4. Gugatan ini diajukan ke Pengadilan Negeri, dengan ancaman hukuman pidana penjara maksimum 2 tahun penjara dan atau denda maksimum Rp 300.000.000,(tiga ratus juta rupiah). Tindak pidana Rahasia Dagang merupakan delik aduan. **

\section{Contoh kasus}

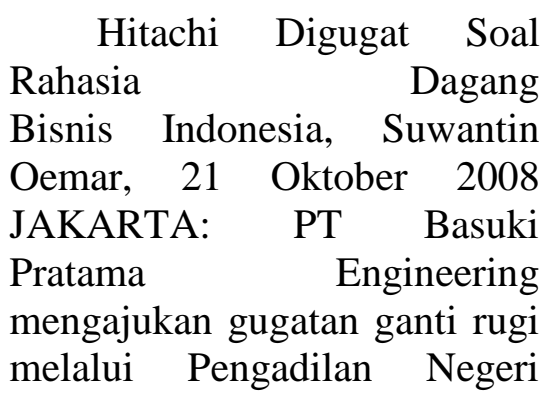


Gugatan PT BPE itu dikabulkan oleh majelis hakim Namun, PT HCMI diketahui mengajukan kasasi ke Mahkamah Agung atas putusan Pengadilan Niaga Jakarta Pusat.

Sementara itu, kuasa hukum PT HCMI, Otto Hasibuan, mengatakan pengajuan gugatan pelanggaran rahasia dagang oleh PT BPE terhadap mantanmantan karyawannya dan PT HCMI pada prinsipnya sama dengan pengaduan ataupun gugatan BPE sebelumnya.

Gugatan itu, menurut Otto Hasibuan, dalam pernyataannya yang diterima Bisnis, dilandasi oleh tuduhan BPE terhadap mantan karyawannya bahwa mereka telah mencuri rahasia dagang berupa metode produksi dan metode penjualan mesin boiler. Padahal, ujarnya, mantan karyawan BPE yang memilih untuk pindah kerja hanya bermaksud untuk mencari dan mendapatkan penghidupan yang layak dan ketenteraman dalam bekerja, dan sama sekali tidak melakukan pelanggaran rahasia dagang ataupun peraturan perusahaan BPE. Bahkan, menurutnya, karyawan itu telah banyak memberikan kontribusi terhadap BPE dalam mendesain mesin boiler.

Dia menjelaskan konstitusi dan hukum Indonesia, khususnya UU No 13 Tahun 2003 tentang Ketenagakerjaan, telah memberikan jaminan dan perlindungan terhadap hak-hak asasi pekerja, termasuk hak untuk pindah kerja.HCMI optimistis gugatan BPE tersebut tidak berdasar "HCMI percaya majelis hakim akan bersikap objektif, sehingg gugatan BPE tersebut akan ditolak," ujarnya

\section{B. CONTENT}

Rahasia dagang adalah informasi yang tidak diketahui oleh umum di bidang teknologi dan/ atau bisnis dimana mempunyai nilai ekonomis karena berguna dalam kegiatan usaha, dan dijaga kerahasiaannya oleh pemilik rahasia dagang.

Seperti yang disebutkan dalam Pasal 1 Undang-Undang Rahasia Dagang (UndangUndang Nomor 30 Tahun 2000)yang berbunyi, Rahasia Dagang adalah informasi yang tidak diketahui oleh umum di bidang teknologi dan/atau bisnis, mempunyai nilai ekonomi karena berguna dalam kegiatan usaha, dan dijaga kerahasiaannya oleh pemilik Rahasia Dagang. Lingkup perlindungan rahasia dagang meliputi metode produksi, metode pengolahan, metode penjualan, atau informasi lain di bidang teknologi dan/atau bisnis yang memiliki nilai ekonomi dan tidak diketahui oleh masyarakat umum. Rahasia dagang mendapat perlindungan apabila informasi itu: 
- Bersifat rahasia hanya diketahui oleh pihak tertentu bukan secara umum oleh masyarakat,

- Memiliki nilai ekonomi apabila dapat digunakan untuk menjalankan kegiatan atau usaha yg bersifat komersial atau dapat meningkatkan keuntungan ekonomi, - Dijaga kerahasiaannya apabila pemilik atau para pihak yang menguasainya telah melakukan langkah-langkah yang layak dan patut. Pemilik rahasia dagang dapat memberikan lisensi bagi pihak lain. Yang dimaksud dengan lisensi adalah izin yang diberikan kepada pihak lain melalui suatu perjanjian berdasarkan pada pemberian hak (bukan pengalihan hak) untuk menikmati manfaat ekonomi dari suatu rahasia dagang yang diberikan perlindungan pada jangka waktu tertentu dan syarat tertentu.

Tidak dianggap sebagai pelanggaran rahasia dagang apabila:

- $\quad$ Mengungkap untuk kepentingan hankam, kesehatan, atau keselamatan masyarakat,

- Rekayasa ulang atas produk yang dihasilkan oleh penggunaan rahasia dagan milik orang lain yang dilakukan semata-mata untuk kepentingan pengembangan lebih lanjut produk yang bersangkutan.

\section{B.Perkembangan Pengaturan Rahasia Dagang}

Pengaturan tentang rahasia dagang di Indonesia masih baru. Dasar dari pengaturan ini adalah diratifikasinya Agreement Establishing the World Trade Organization (persetujuan Pembentukan Organisasi Perdagang Dunia atau WTO) yang mencakup juga Agreement on Trade Related Aspects of Intellectual Property Rights (Persetujuan TRIPs) dengan UndangUndang No. 7 Tahun 1994 sehingga perlu diatur tentang rahasia dagang. Di Indonesia rahasia dagang diatur pertama kali melalui Undang-Undang No. 30 Tahun 2000 Tentang Rahasia Dagang. Pada awalnya perlindungan hukum menyangkut segala bentuk praktek-praktek persaingan tidak sehat telah diatur oleh rambu-rambu dan normanorma pada Pasal 1365 KUHPerdata dan Pasal 382 bis KUHP.

Namun kemudian menjadi masalah setelah tentang hal itu dikemas sebagai produk kekayaan intelektual. Ini berarti konsep unfair competition sebagai hukum yang bersifat umum lebih dipersempit atau difokuskan kepada hukum yang melindungi adanya praktek curang bermotif komersial. Kebuthan itu diformulasikan dalam Undang-Undang No. 30 Tahun 2000 Tentang Rahasia Dagang. Secara umum dapat 
dikatakan bahwa undangundang rahasia dagang ini juga melengkapi Undang-Undang No. 5 Tahun 1999 tentang Larangan Praktek Monopoli dan Persaingan Usaha Tidak Sehat.

\section{C.Lingkup Rahasia Dagang}

a. Subyek Rahasia dagang adalah pemilik rahasia dagang. Pemilik rahasia dagang memiliki hak untuk : 1) Menggunakan sendiri Rahasia Dagang yang dimilikinya;

2) Memberi lisensi kepada pihak lain atau melarang pihak lain untuk menggunakan Rahasia Dagang atau mengungkapkan Rahasia Dagang itu kepada pihak ketiga untuk kepentingan yang bersifat komersial.

b. Obyek ruang lingkup rahasia dagang menurut undang-undang No. 30 Tahun 2000 Pasal 2 meliputi metode produksi, metode pengolahan, metode penjualan atau informasi lain di bidang tekhnologi dan/atau bisnis yang memiliki nilai ekonomi dan tidak diketahui oleh masyarakat umum. Misalnya Coca-cola menggunakan rahasia dagang yaitu informasi teknik senyawa untuk melindungi formulanya, bukan paten. Hal ini untuk menghindari adanya batas waktu. Kalau formula dilindungi hak paten maka, akan berakhir paling lama 20 tahun. Pada saat ini usia Coca Cola sudah lebih dari 100 tahun, hak ini karena formulanya dilindungi dengan rahasia dagang. Metode produksi misalnya teknologi pemrosesan anggur, formula ramuan rokok. Di bidang lain, misalnya informasi non teknik. Data mengenai pelanggan, data analisis, administasi keuangan, dll.

c. Lama Perlindungan Beberapa alasan/keuntungan penerapan Rahasia Dagang dibandingkan Paten adalah karya intelektual tidak memenuhi persyaratan paten, masa perlindungan yang tidak terbatas, proses perlindungan tidak serumit dan semahal paten, lingkup dan perlindungan geografis lebih luas.Namun, tanpa batas waktu ini mempunyai syarat yaitu sebagaimana tercantum dalam Pasal 3 yaitu bahwa rahasia dagang dilindungi bila informasi tersebut masih bersifat rahasia, mempunyai nilai ekonomi, dan dijaga kerahasiaannya melalui upaya semestinya. Ketiga syarat yang harus dipenuhi itu dapat diuraikan sebagai berikut. a) Bersifat rahasia apabila informasi itu hanya diketahui oleh orang-orang terbatas. b) Informasi mempunyai nilai ekonomi apabila sifat kerahasiaan informasi tersebut dapat digunakan untuk menjalankan kegiatan usaha atau bisnis yang komersial atau mendatangkan keuntungan bagi 
pemiliknya.

c) dijaga kerahasiaannya apabila pemilik atau para pihak yang menguasainya telah melakukan langkah-langkah yang layak.

\section{D.Pelanggaran dan Sanksi} Barangsiapa dengan sengaja dan tanpa hak menggunakan dan mengungkapkan Rahasia Dagang, mengingkari kesepakatan atau mengingkari kewajiban tertulis atau tidak tertulis untuk menjaga Rahasia Dagang yang bersangkutan, atau pihak lain yang memperoleh/menguasai

Rahasia Dagang tersebut dengan cara yang bertentangan dengan peraturan perundangundangan yang berlaku, dipidana dengan pidana penjara paling lama 2 (dua) tahun dan/atau denda paling banyak Rp 300.000.000,00 (tiga ratus juta

rupiah).

\section{E.Prosedur Perlindungan} Untuk mendapat perlindungan Rahasia Dagang tidak perlu diajukan pendaftaran (berlangsung secara otomatis), karena undang-undang secara langsung melindungi Rahasia Dagang tersebut apabila informasi tersebut bersifat rahasia, bernilai ekonomis dan dijaga kerahasiaannya, kecuali untuk lisensi Rahasia Dagang yang diberikan. Lisensi Rahasia Dagang harus dicatatkan ke Ditjen. HKI DepkumHAM.

\section{CONCLUSION}

Rahasia dagang adalah informasi yang tidak diketahui oleh umum di bidang teknologi dan/ atau bisnis dimana mempunyai nilai ekonomis karena berguna dalam kegiatan usaha, dan dijaga kerahasiaannya oleh pemilik rahasia dagang.

Seperti yang disebutkan dalam Pasal 1 Undang-Undang Rahasia Dagang (Undang-Undang Nomor 30 Tahun 2000)yang berbunyi, Rahasia Dagang adalah informasi yang tidak diketahui oleh umum di bidang teknologi dan/atau bisnis, mempunyai nilai ekonomi karena berguna dalam kegiatan usaha, dan dijaga kerahasiaannya oleh pemilik Rahasia Dagang.

Pemilik rahasia dagang dapat memberikan lisensi bagi pihak lain. Yang dimaksud dengan lisensi adalah izin yang diberikan kepada pihak lain melalui suatu perjanjian berdasarkan pada pemberian hak (bukan pengalihan hak) untuk menikmati manfaat ekonomi dari suatu rahasia dagang yang diberikan perlindungan pada jangka waktu tertentu dan syarat tertentu. Tidak dianggap sebagai pelanggaran rahasia dagang apabila:

- Mengungkap untuk kepentingan hankam, kesehatan, atau keselamatan masyarakat,

- Rekayasa ulang atas produk yang dihasilkan oleh penggunaan rahasia dagan milik orang lain yang dilakukan semata-mata untuk kepentingan pengembangan lebih lanjut produk yang bersangkutan. 
Contoh kasus

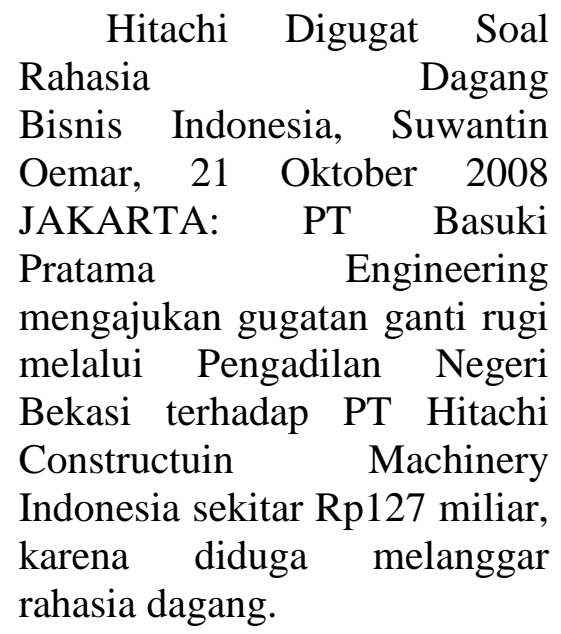

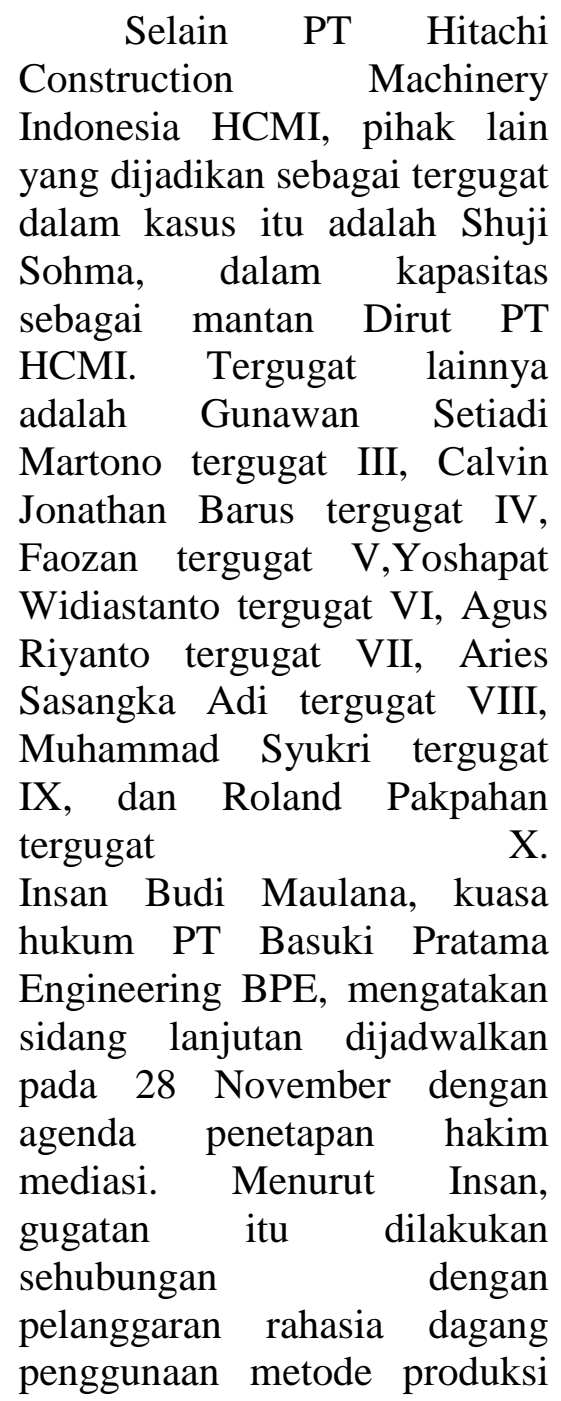

dan atau metode penjualan mesin boiler secara tanpa hak. PT BPE bergerak dalam bidang produksi mesin-mesin industri, dengan produksi awal mesin pengering kayu.

Penggugat, katanya, adalah pemilik dan pemegang hak atas rahasia dagang metode produksi dan metode penjualan mesin boiler di Indonesia "Metode proses produksi itu sifatnya rahasia perusahaan," katanya.

Dia menjelaskan bahwa tergugat IV sampai dengan tergugat $\mathrm{X}$ adalah bekas karyawan PT BPE, tetapi ternyata sejak para tergugat tidak bekerja lagi di perusahaan, mereka telah bekerja di perusahaan tergugat PT HCMI.

Tergugat, katanya, sekitar tiga sampai dengan lima tahun lalu mulai memproduksi mesin boiler dan menggunakan metode produksi dan metode penjualan milik penggugat yang selama ini menjadi rahasia dagang PT BPE. PT BPE, menurutnya, sangat keberatan dengan tindakan tergugat I baik secara sendiri-sendiri maupun secara bersama-sama memproduksi mesin boiler dengan menggunakan metode produksi dan metode penjualan mesin boiler penggugat secara tanpa izin dan tanpa hak. 


\section{DISCUSSION}

Rahasia dagang adalah informasi yang tidak diketahui oleh umum di bidang teknologi dan/ atau bisnis dimana mempunyai nilai ekonomis karena berguna dalam kegiatan usaha, dan dijaga kerahasiaannya oleh pemilik rahasia dagang.

Seperti yang disebutkan dalam Pasal 1 Undang-Undang Rahasia Dagang (Undang-Undang Nomor 30 Tahun 2000)yang berbunyi, Rahasia Dagang adalah informasi yang tidak diketahui oleh umum di bidang teknologi dan/atau bisnis, mempunyai nilai ekonomi karena berguna dalam kegiatan usaha, dan dijaga kerahasiaannya oleh pemilik Rahasia Dagang.

Pemilik rahasia dagang dapat memberikan lisensi bagi pihak lain. Yang dimaksud dengan lisensi adalah izin yang diberikan kepada pihak lain melalui suatu perjanjian berdasarkan pada pemberian hak (bukan pengalihan hak) untuk menikmati manfaat ekonomi dari suatu rahasia dagang yang diberikan perlindungan pada jangka waktu tertentu dan syarat tertentu. Tidak dianggap sebagai pelanggaran rahasia dagang apabila:

- Mengungkap untuk kepentingan hankam, kesehatan, atau keselamatan masyarakat,

- Rekayasa ulang atas produk yang dihasilkan oleh penggunaan rahasia dagan milik orang lain yang dilakukan semata-mata untuk kepentingan pengembangan lebih lanjut produk yang bersangkutan.

\section{Contoh kasus}

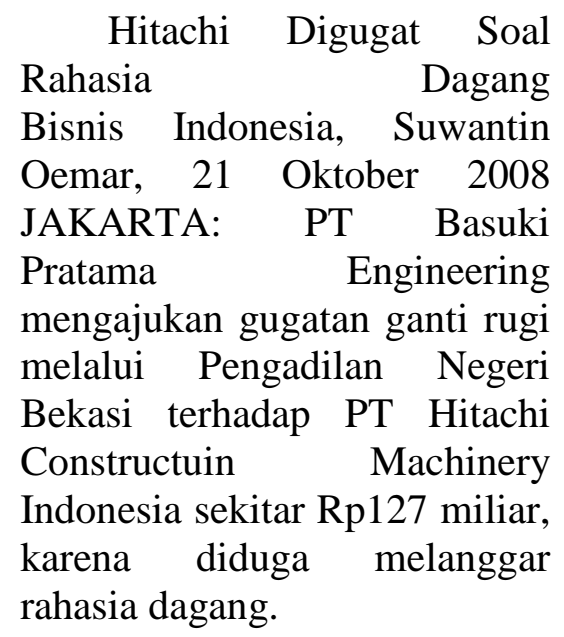

Selain PT Hitachi Construction Machinery Indonesia HCMI, pihak lain yang dijadikan sebagai tergugat dalam kasus itu adalah Shuji Sohma, dalam kapasitas sebagai mantan Dirut PT HCMI. Tergugat lainnya adalah Gunawan Setiadi Martono tergugat III, Calvin Jonathan Barus tergugat IV, Faozan tergugat V,Yoshapat Widiastanto tergugat VI, Agus Riyanto tergugat VII, Aries Sasangka Adi tergugat VIII, Muhammad Syukri tergugat IX, dan Roland Pakpahan tergugat $\mathrm{X}$. Insan Budi Maulana, kuasa hukum PT Basuki Pratama Engineering BPE, mengatakan sidang lanjutan dijadwalkan pada 28 November dengan agenda penetapan hakim mediasi. Menurut Insan, gugatan itu dilakukan sehubungan dengan pelanggaran rahasia dagang penggunaan metode produksi 
dan atau metode penjualan mesin boiler secara tanpa hak. PT BPE bergerak dalam bidang produksi mesin-mesin industri, dengan produksi awal mesin pengering kayu.

Penggugat, katanya, adalah pemilik dan pemegang hak atas rahasia dagang metode produksi dan metode penjualan mesin boiler di Indonesia "Metode proses produksi itu sifatnya rahasia perusahaan," katanya.

Dia menjelaskan bahwa tergugat IV sampai dengan tergugat $\mathrm{X}$ adalah bekas karyawan PT BPE, tetapi ternyata sejak para tergugat tidak bekerja lagi di perusahaan, mereka telah bekerja di perusahaan tergugat PT HCMI.

Tergugat, katanya, sekitar tiga sampai dengan lima tahun lalu mulai memproduksi mesin boiler dan menggunakan metode produksi dan metode penjualan milik penggugat yang selama ini menjadi rahasia dagang PT BPE. PT BPE, menurutnya, sangat keberatan dengan tindakan tergugat I baik secara sendiri-sendiri maupun secara bersama-sama memproduksi mesin boiler dengan menggunakan metode produksi dan metode penjualan mesin boiler penggugat secara tanpa izin dan tanpa hak.

\section{E. REFERENCE}

[1] O. M. Febriani and A. S. Putra, "Sistem Informasi Monitoring Inventori Barang Pada Balai Riset Standardisasi Industri Bandar Lampung," J. Inform., vol. 13, no. 1, pp. 90-98, 2014.

[2] A. S. Putra, "Paperplain: Execution Fundamental Create Application With Borland Delphi 7.0 University Of Mitra Indonesia," 2018.

[3] A. S. Putra, "2018 Artikel Struktur Data, Audit Dan Jaringan Komputer," 2018.

[4] A. S. Putra, "ALIAS MANAGER USED IN DATABASE DESKTOP STUDI CASE DB DEMOS."

[5] A. S. Putra, "COMPREHENSIVE SET OF PROFESSIONAL FOR DISTRIBUTE COMPUTING."

[6] A. S. Putra, "DATA ORIENTED RECOGNITION IN BORLAND DELPHI 7.0."

[7] A. S. Putra, "EMBARCADERO DELPHI XE 2 IN GPUPOWERED FIREMONKEY APPLICATION."

[8] A. S. Putra, "HAK ATAS KEKAYAAN INTELEKTUAL DALAM DUNIA TEKNOLOGY BERBASIS REVOLUSI INDUSTRI 4.0."

[9] A. S. Putra, "IMPLEMENTASI PERATURAN

PERUNDANGAN UU. NO 31 TAHUN 2000 TENTANG DESAIN INDUSTRI BERBASIS INFORMATION TECHNOLOGY." 
[10] A. "IMPLEMENTATION PARADOX DBASE."

A. $\mathrm{S}$. "IMPLEMENTATION TRADE SECRET CASE STUDY SAMSUNG MOBILE PHONE."

[12] A.

"IMPLEMENTATION

PATENT FOR APPLICATION WEB BASED CASE STUDI WWW. PUBLIKLAMPUNG. COM."

[13] A. "IMPLEMENTATION SYSTEM FIRST TO INVENT IN DIGITALLY INDUSTRY."

[14] A. S. Putra, "MANUAL REPORT \& INTEGRATED DEVELOPMENT

ENVIRONMENT BORLAND DELPHI 7.0."

[15] A. S. Putra, "PATENT AS RELEVAN SUPPORT RESEARCH."

[16] A. S. Putra, "PATENT FOR RESEARCH STUDY CASE OF APPLE. Inc."

[17] A. S. Putra, "PATENT PROTECTION FOR APPLICATION INVENT."

[18] A. S. Putra, "QUICK REPORT IN PROGRAMMING."'

[19] A. S. Putra, "REVIEW CIRCUIT LAYOUT COMPONENT

REQUIREMENT ON ASUS NOTEBOOK."

[20] A. S. Putra, "REVIEW TRADEMARK PATENT FOR INDUSTRIAL TECHNOLOGY BASED 4.0.”

[21] A. S. Putra, "TOOLBAR
COMPONENT PALLETTE IN OBJECT ORIENTED PROGRAMMING."

[22] A. S. Putra, "WORKING DIRECTORY SET FOR PARADOX 7."

[23] A. S. Putra, "ZQUERY CONNECTION

IMPLEMENTED

PROGRAMMING STUDI CASE PT. BANK BCA Tbk."

[24] A. S. Putra, D. R. Aryanti, and I. Hartati, "Metode SAW (Simple Additive Weighting) sebagai Sistem Pendukung Keputusan Guru Berprestasi (Studi Kasus: SMK Global Surya)," in Prosiding Seminar Nasional Darmajaya, 2018, vol. 1, no. 1, pp. 85-97.

[25] A. S. Putra and O. M. Febriani, "Knowledge Management Online Application in PDAM Lampung Province," in Prosiding International conference on Information Technology and Business (ICITB), 2018, pp. 181-187.

[26] A. S. Putra, O. M. Febriani, and B. Bachry, "Implementasi Genetic Fuzzy System Untuk Mengidentifikasi Hasil Curian Kendaraan Bermotor Di Polda Lampung," SIMADA (Jurnal Sist. Inf. dan Manaj. Basis Data), vol. 1, no. 1, pp. 21-30, 2018.

[27] A. S. Putra, H. Sukri, and K. Zuhri, "Sistem Monitoring Realtime Jaringan Irigasi Desa (JIDES) Dengan Konsep Jaringan Sensor Nirkabel," IJEIS (Indonesian J. Electron. Instrum. Syst., vol. 8, no. 2, pp. 221-232. 
[28] D. P. Sari, O. M. Febriani, and A. S. Putra, "Perancangan Sistem Informasi SDM Berprestasi pada SD Global Surya," in Prosiding Seminar Nasional Darmajaya, 2018, vol. 1, no. 1, pp. 289-294. 